\title{
Application of DNA Fingerprinting to Confirmation of Clone in $\mathrm{Ayu}^{* 1}$
}

\author{
Hyon-Sob Han, ${ }^{* 2}$ Hideyuki Mannen, ${ }^{* 3}$ Akio Tsujimura, ${ }^{* 4}$ \\ and Nobuhiko Taniguchi*2 \\ (Received May 8, 1992)
}

\begin{abstract}
In order to determine the effectiveness of DNA fingerprinting as a tool for confirmation of clonal nature and identity, we applied a DNA fingerprinting method to three genetically different groups of ayu Plecoglossus altivelis: clonal diploid, mitotic gynogenetic diploid (mitotic-G2N) and normal diploid. Genomic DNA extracted from blood was digested by $P$ st $I$ restriction endonuclease and was hybridized with repetitive sequence in bacteriophage M13 DNA labelled with $\left[\alpha{ }^{32} \mathrm{P}\right]$ isotope. DNA fingerprints of $P$. altivelis were detected over the whole effective fraction range from $0.5-25$ Kilobase pairs, and more than 42 fragment patterns were detected. The DNA fingerprints of clonal fish consisted of at least 21 distinguishable bands which showed identical patterns within a clone. Mitotic-G2N consisted of 12-18 bands, and an individual fingerprint of this group hardly shared the bands of the other individuals. A trend of markedly low levels of band sharing in the DNA fingerprint among individuals of mitotic-G2N fish would be useful as a powerful genetic marker for their respective clonal lines. In N-CONT, 9 of the 18-24 distinguishable bands were shared. These results suggest the usefulness of DNA fingerprinting in fisheries genetics as a marker for the assessment of inbreeding rates, and also for the identification of individuals and families.
\end{abstract}

Over the past twenty years, several techniques from biochemical and molecular genetics such as enzyme electrophoresis and isoelectric focusing have been widely and successfully applied to the study of population differentiation and evolution. However, they have been less applicable to demographic problems such as assigning parentage to individuals within a population. The search for new and more sensitive techniques for detecting genetic variation and genetic markers has continued, and recently a major discovery has been made by molecular biology.

DNA fingerprinting, which belongs to one of the genetic markers, has recently proved to be an extremely powerful tool for the identification of individuals, ${ }^{1)}$ the construction of pedigrees, ${ }^{2,3}$ and the genetic analysis of populations. ${ }^{4-7)}$ DNA fingerprinting has been developed for humans by Jeffreys et $a l^{8}{ }^{8}$ and is a technique based on short DNA sequences which are usually 10 to 40 base pairs (bp) long and are repeated in tandem a variable number of times. A single probe derived from the 'core' repeat sequence, when used under hybridization conditions at low stringency, can reveal a large number of loci simultaneously. Highly polymorphic patterns detected using M13 bacteriophage DNA as a hybridization probe (DNA fingerprints ${ }^{\theta}$ ) have been found in a variety of animals ${ }^{4,10-12}$ and the patterns are inherited as stable genetic traits.

The potential applications of hypervariable DNA markers to fisheries science has been reviewed by Hallerman and Beckmann, ${ }^{13)}$ and the occurrence of DNA fingerprints in a few fish species has been reported. $2,3,10,14,15)$

In this study, we applied DNA fingerprinting obtained by hybridizing with repetitive sequence in bacteriophage M13 DNA to the confirmation of clonal fish produced in ayu Plecoglossus altivelis and also to the evaluation of genetic polymorphism of DNA fingerprinting as a marker for the identification of each clonal line of mitotic

*1 Partly presented at the annual meeting of the Japan. Soc. Sci. Fish., Tokyo, 1992.

*2 Department of Cultural Fisheries, Faculty of Agriculture, Kochi University, Nankoku, Kochi 783, Japan

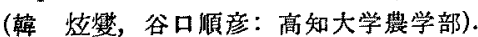

*3 Division of Science of Biological Resources, The Graduate School of Science and Technology, Kobe University, Kobe, Hyogo 657, Japan (万年英之：神局大学大学院).

*4 Wakayama Prefecture Freshwater Fisheries Center, Momoyama, Wakayama 649-61, Japan (汢村明夫: 和歌山其内水面漁業もンター). 
gynogenetic diploids (complete homozygous diploid) induced by suppressing the first cleavage. Normal diploid individuals were also used to determine if DNA fingerprinting could be applied to pedigree analysis.

\section{Materials and Methods}

\section{Fish Samples}

Fish samples examined in this study were 5 for mitotic gynogenetic diploid (abbreviated as mitotic-G2N), 5 for clonal fish, and 5 for the normal diploid (abbreviated as N-CONT) in $P$. altivelis.

A smelt species Spirinchus lanceolata, shishamo, which belongs to a different family from $\boldsymbol{P}$. altivelis, was obtained from Hokkaido to be used as a donor of sperm. The sperm of $S$. lanceolata was applied to induce mitotic-G2N as a marker for the confirmation of $\boldsymbol{P}$. altivelis gynogenetic diploids. ${ }^{16)}$ The eggs of $P$. altivelis were collected from three breeders captured at a natural spawning ground and were inseminated with the sperm of the $S$. lanceolata which had been genetically inactivated by ultraviolet light (UV) with a dose of approximately $7000 \mathrm{erg} / \mathrm{mm}^{2}$. The treatment for the suppression of the first cleavage was done with a hydrostatic pressure of $650 \mathrm{~kg} / \mathrm{cm}^{2}$ administered for $6 \mathrm{~min}, 80 \mathrm{~min}$ after insemination as described by Taniguchi et al. ${ }^{17)}$ Sperm for N-CONT was used from two males of $\boldsymbol{P}$. altivelis. The clonal fish were produced using the procedures of Han et al. ${ }^{18)}$ A mature female of mitoticG2N was used as a parental fish. The inactivation of sperm and the treatment for diploidization were carried out using the methods of Taniguchi et al. ${ }^{19)}$

\section{$D N A$ extraction and Digestion}

Genomic DNA was extracted from the blood of the 15 fish. Approximately $0.4 \mathrm{ml}$ of the whole blood was taken by using a heparinized syringe. Cells were sedimented by centrifugation, washed once in $0.9 \%$ saline solution including EDTA $1 \mathrm{~mm}$, and resuspended in $800 \mu \mathrm{l}$ of $1 \%$ Triton $\mathrm{X}-100$ (including $0.32 \mathrm{M}$ sucrose, $10 \mathrm{~mm}$ Tris- $\mathrm{HCl} \mathrm{pH} 8.0$, and $5 \mathrm{mM} \mathrm{MgC1}_{2}$ ). Cells were lysed by adding $10 \mathrm{~m} l$ of lysis solution $(0.5 \% N$-lauroylsarcosine sodium salt, $10 \mathrm{~mm}$ Tris- $\mathrm{HCl} \mathrm{pH} \mathrm{8.0,} \mathrm{and} 10 \mathrm{~mm}$ EDTA) and $100 \mu \mathrm{g} / \mathrm{m} l$ of proteinase $\mathrm{K}$. The mixtures were incubated overnight at $37^{\circ} \mathrm{C}$. The solution was extracted once with TE-phenol and chloroform, respectively, and the DNA was precipitated by adding 2 volumes of $99 \%$ cold ethanol. The precipitated DNA was then dialysed by TE buffer $(10 \mathrm{mM}$ Tris- $\mathrm{HCl}$ pH 8.0 and $1 \mathrm{~mm}$ EDTA). The DNA extracted from each fish was digested overnight with Pst I restriction endonuclease according to its manufacturer's specifications under standard conditions. The digested DNA was extracted again with phenol-chloroform, precipitated with 2.5 volumes of $99 \%$ cold ethanol and washed once with $70 \%$ ethanol. It was dried and resuspended in TE buffer. The DNA was fractionated by electrophoresis through $1.2 \%$ agarose gel $2 \mathrm{~V} / \mathrm{cm}$ for $43 \mathrm{~h}$ in $1 \times \mathrm{TAE}(0.4 \mathrm{M}$ Tris, $0.4 \mathrm{M} \mathrm{NaCl}$, and $1 \mathrm{~mm}$ EDTA, pH 7.7) buffer. It was then transferred from the gel onto Hybond-N filters (Amersham Corp., Illinois) by Southern blotting ${ }^{20)}$ in $0.5 \mathrm{M}$ $\mathrm{NaOH}$ and $1.5 \mathrm{~m} \mathrm{NaCl}$. It was finally fixed to the filter by UV for $3 \mathrm{~min}$ at $302 \mathrm{~nm}$.

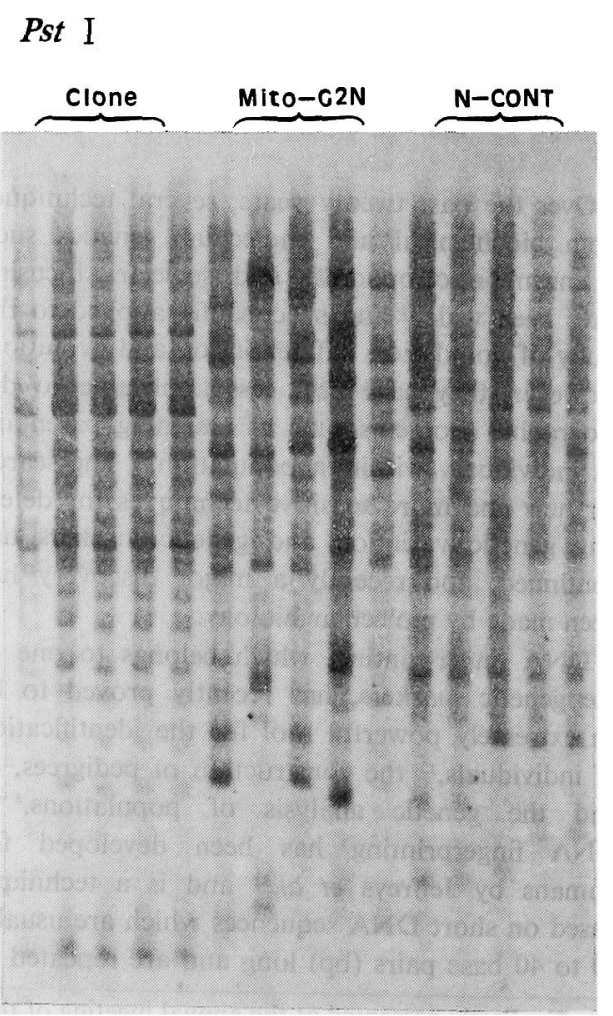

Fig. 1. DNA fingerprints of Ayu. Genomic DNA was digested by Pst I and was hybridized with radiolabelled bacteriophage M13 DNA. Counting from the left, lanes 1-5: clonal lines, lanes 6-10: mitotic gynogenetic diploids and lanes 11-15: normal diploid individuals. 


\section{Probe Labelling and Hybridization}

The M13 bacteriophage DNA by Vassart et $a l_{.9}^{9)}$ was used as a probe. The M13 DNA was labelled with $\left[\alpha^{-{ }^{32}} \mathrm{P}\right]-\mathrm{dCTP}$ by oligonucleotide priming extension:1) to a specific activity of $1.1 \times 10^{9} \mathrm{cpm} / \mu \mathrm{g}$.

The filter was prehybridized for $3 \mathrm{~h}$ in a solution containing $40 \%$ formamide, $5 \mathrm{~mm}$ EDTA, $6 \times \mathrm{SSC}$ $(1 \times \mathrm{SSC}: 0.15 \mathrm{M} \mathrm{NaCl}$ and $0.015 \mathrm{M}$ citrate trisodium salt, $\mathrm{pH} 7.4$ ), $1 \%$ SDS (sodium dodecysulphate), and $50 \mu \mathrm{g} / \mathrm{m} l$ heparin sodium salt at $37^{\circ} \mathrm{C}$. The heat-denatured probe was added to it and hybridization was allowed to proceed at $42^{\circ} \mathrm{C}$ overnight. The filter was washed twice with $4 \times \mathrm{SSC}$ and $0.1 \%$ SDS for $5 \mathrm{~min}$ at room temperature and once with $2 \times \mathrm{SSC}$ and $0.1 \%$ SDS for $30 \mathrm{~min}$ at $60^{\circ} \mathrm{C}$ respectively. The filter was wrapped in cling-film and exposed to X-ray film (Fuji Super HR-A) with an intensifying screen for 2 days at $-80^{\circ} \mathrm{C}$.

\section{DNA Fingerprinting Evaluation}

As a measure of genetic similarity and variability, we calculated and compared band-sharing indices (BSI) between the individuals within each group and between the genetically different groups of $P$. altivelis. The BSI between two individuals is $2 \mathrm{~N}_{A B} /\left(\mathrm{N}_{\mathbf{A}}+\mathrm{N}_{B}\right)$, where $\mathrm{N}_{A}$ and $\mathrm{N}_{B}$ are the total numbers of bands scored in individuals $A$ and $B$, and $N_{A B}$ is the number of bands shared by both. ${ }^{22}$ The value varies from zero when there are no bands in common to 1 when the two lanes are identical. In order to reduce ambiguities, the samples were run on the same gel. All visible bands were considered for analysis.

\section{Results}

The bacteriophage M13 DNA probe was hybridized with blots of Pst I digested genomic DNA from $P$. altivelis. The resultant autoradiograph is shown in Fig. 1. It shows the DNA fingerprinting pattern of clonal fish (in lanes 1-5 from the left), the mitotic- $G 2 \mathrm{~N}$ individuals (lanes 6-10) and the N-CONT (lanes 11-15). These $P$. altivelis minisatellite fragments are highly variable and constitute individual specific DNA fingerprints, as reported for several other fish species. ${ }^{2,3,10,14,15)}$ From all the fragment patterns, a total of more than 42 band patterns were detected in P. altivelis. The pattern of DNA fingerprints of $P$. altivelis which digested with $P s t \mathbf{I}$ was detected over the whole effective fraction range of the gel (0.5-25 kilobase pairs (kbp)).

For statistical analysis the BSI values were estimated by comparing the shared bands of the total bands based on Fig. 1, and the estimated results are shown in Table 1.

The patterns of clonal fish consisted of at least 21 distinguishable bands, which were all shared,

Table 1. The value of BSI between genetically different groups and between each individuals examined

(mean $\pm S D$ )

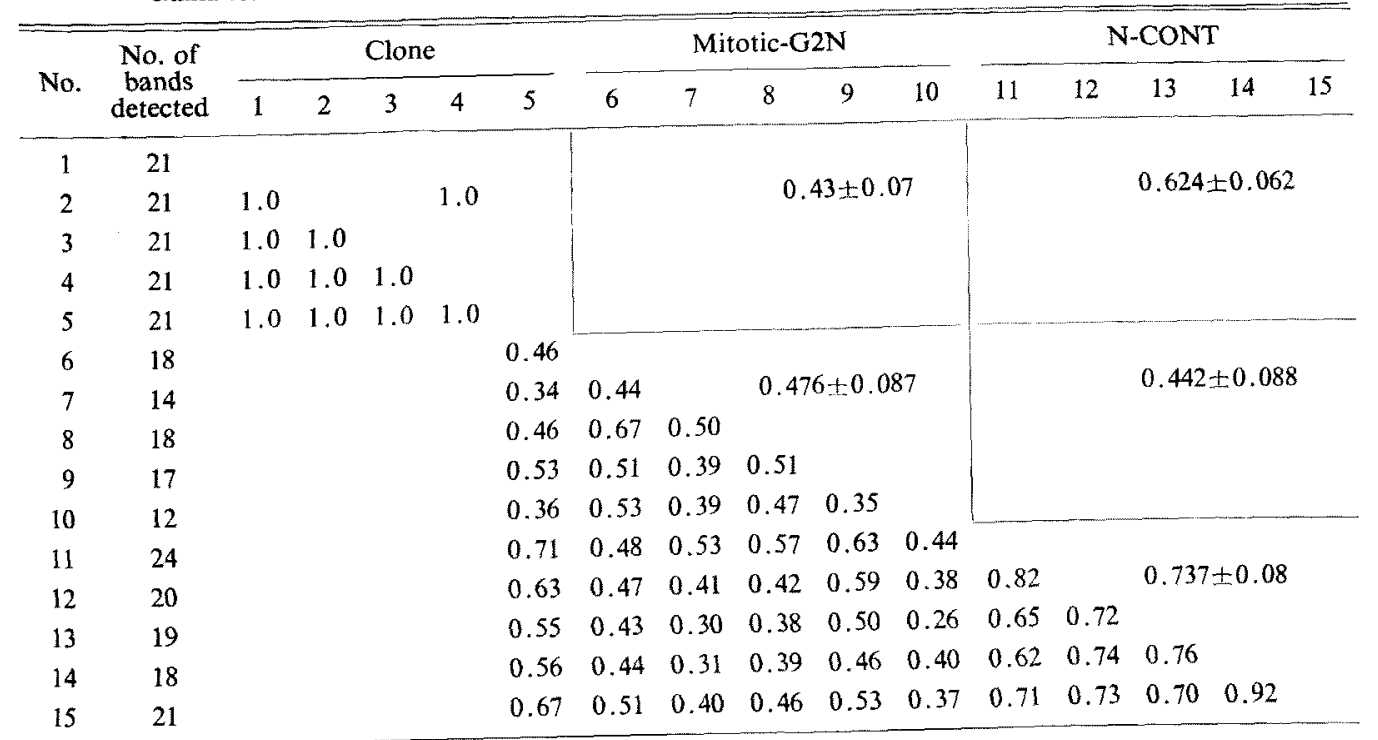

* These values were obtained by comparing the shared bands from the total fragment. 
and showed identical fingerprints for all the individuals. The BSI value was equal to 1 within a family of a clonal line.

The fingerprint patterns of mitotic-G2N consisted of 12-18 distinguishable bands for each individual. However, in these fingerprints, five individuals hardly shared their bands. Only one of the bands was shared by them, and it was independent. The average value of BSI within mitotic-G2N was $0.476(\mathrm{SD}=0.087)$.

In N-CONT fish, the fingerprinting patterns consisted of 18-24 distinguishable bands for each individual. In this group more than 26 bands were detected, and nine of them were shared. The average value of BSI within this group was 0.737 ( $\mathrm{SD}-0.08$ ). The average $\mathrm{BSI}$ values obtained by comparison between genetically different groups were: $0.43(\mathrm{SD}=0.07)$ for clonal line versus mitotic-G2N, $0.624(\mathrm{SD}=0.062)$ for clonal line versus $\mathrm{N}-\mathrm{CONT}$, and $0.442 \quad(\mathrm{SD}=0.088)$ for mitotic- $\mathrm{G} 2 \mathrm{~N}$ versus $\mathrm{N}-\mathrm{CONT}$.

\section{Discussion}

This study has revealed that the becteriophage M13 DNA probe hybridized to genomic DNA of $P$. altivelis digested with $P$ st I produced extremely complex band patterns. A large number of fragments resolved, coupled with a low level of band-sharing detected, resulted in highly individual specific DNA fingerprints. In common with similar studies in other vertebrates (i.e. humans, ${ }^{23)}$ cats and dogs, ${ }^{24}$ poultry, ${ }^{25)}$ and wild birds), ${ }^{26)}$ minisatellite loci have been found to show Mendelian inheritance. They are stable both somatically and in the germline, and appear to be widely dispersed throughout the genome.

In the present study, we examined three genetically different groups of $P$. altivelis. DNA fingerprints of clonal fish were composed of 21 distinguishable bands, and all of them were shared. This result strongly suggests that the polymorphism displayed within a single clonal line is completely identical. Therefore, DNA fingerprinting may make it possible to verify its clonal nature and identity. In addition, this would suggest that DNA fingerprinting together with tissue grafting ${ }^{1 B}$ may be a complete methodology in verifying clonal fish.

The mitotic-G2N showed patterns specific to individuals with fewer shared bands than those for the N-CONT. The value of BSI within mitotic-G2N was lower than the one for clonal fish and N-CONT, and the number of bands also decreased. These results might have been caused by the non-contribution of the paternal genome and the elimination of heterozygosity. It is known that the fixation index or coefficient of inbreeding increases markedly in gynogenetic diploids. ${ }^{27)}$ Taniguchi et al. observed the increase of genetic variation in quantitative characters and the genetic homozygous property of individuals in mitotic-G2N of $\boldsymbol{P}$. altivelis. ${ }^{28}$ Similar phenomena were observed in the genome DNA minisatellite regions of the mitotic-G2N of $P$. altivelis. This can be applied to monitoring of the increase of genetic variance and the genetic homozygous property in individuals by gynogenetic effect. In addition, a trend of remarkable individual specificity of the mitotic-G2N will become a powerful genetic marker if several clonal lines could be produced from mitotic-G2N fish.

In N-CONT, markedly high levels of bandsharing suggest that the number of parents which were used to produce the N-CONT was small, and reflect the relationships and history of their progeny. Actually, when the N-CONT were produced, only two males and three females were used and the progeny were communally reared. On the other hand, the degree of bandsharing varies depending on the probe and enzyme used.

A combination of the other multi-locus probes and enzymes should enable the relatively straightforward identification of individuals, siblings and extended families within mixed samples. These powerful genetic markers could be widely applied to the studies of cultural populations such as trait linkage analysis and identification of families in performance experiments, and studies of natural populations such as ecological and behavioral genetic examination of microand submicro-geographic genetic differentiation.

\section{Acknowledgments}

We would like to thank Professor N. Goto of Faculty of Agriculture, Kobe University, for his invaluable advice and suggestions. This study was supported by a Grant-in-Aid from the Fisheries Agency, Japan. 


\section{References}

1) A. J. Jeffreys, V. Wilson, and S. L. Thein: Individualspecific 'ingerprints' of human DNA. Nature, 316, 76-79 (1985).

2) J. B. Taggart and A. Ferguson: Minisatellite DNA fingerprints of salmonid fishes. Anim. Genet., 21, 377-389 (1990).

3) A. Meng, R. E. Carter, and D. T. Parkin: The variability of DNA fingerprints in three species of swan. Heredity, 64, 73-80 (1990)

4) U. Kuhnlein, Y. Dawe, D. Zadworny, and J. S. Gavora: DNA fingerprinting: a tool for determining genetic distances between strains of poultry. Theor. Appl. Genet., 77, 669-672 (1989).

5) D. A. Gilbert, N. Lehman, S. J. O'Brien, and R. K. Wayne: Genetic fingerprinting reflects population differentiation in the California Chamnel Island fox. Nature, 344, 764-767 (1990).

6) C. Rico, U. Kuhnlein, and G. J. FitzGerald: Spawning patterns in the three-spined stickleback (Gasterosteus act leatus L.): an evaluation by DNA fingerprinting. $J$. Fish Biol., 39 (Supplement A), 151-158 (1991).

7) I. Wirgin, C. Grunwald, S. J. Garte, and C. Mesing: Use of DNA fingerprinting in the identification and management of a striped bass population in the Southeastern United States. Trans, Amer. Fish, Soc., 120, 273-282 (1991).

8) A. J. Jeffreys, V. Wilson, and S. L. Thein: Hypervariable 'minisatellite' regions in human DNA. Nature, 314, 67-73 (1985).

9) G. Vassart, M. Georges, R. Monsieur, H. Brocas, A. S Lequarre, and D. Christophe: A sequence in M13 phage detects bypervariable minisatellites in human and animal DNA. Science, 235, 683-684 (1987).

10) R. D. Fields, K. R. Johnson, and G. H. Thorgaard: DNA fingerprints in rainbow trout detected by hybridization with DNA of bacteriophage M13. Trans. Amer. Fish. Soc., 118 78-81 (1989).

11) H. Manden, S. Tsuji, and N. Goto: The genome DNA fingerprints of poultry by using $\mathrm{M} 13$ phage. The Japanese J. Zootechnical Sci., 61, 1057-1062 (1990).

12) H. Mannen, T. Fukuda, S. Tsuji, and N. Goto: Usefulnes of DNA fingerprinting for swine. ABRI, 19,39-44 (1991)

13) E. M. Hallerman and J.S. Beckmann: DNA level polymorphisms as a tool in fisheries science. Can. J. Fish. Aquat. Sci., 45, 1075-1087 (1988).

14) A. S. Harris, S. Bieger, W. Doyle, and J. M. Wright: DNA fingerprinting of tilapia, Oreochromis niloticus, and applica- tion to aquaculture genetics. Aquaculture, 92, 157-163 (1991)

15) B. J. Turner, J. F. Elder, $I_{r}$ and T. F. Laughlin: Repetitive DNA sequences and the divergence of fish population: some hopeful beginnings. J. Fish Biol, 39 (Supplement A), 131 142 (1991)

16) N. Taniguchi, H. S. Han, and H. Hatanaka: Induction of diploid gynogenetic ayu by UV-irradiated sperm of shishamo smelt with verification by genetic marker. Suisanzoshoku, 39. $41-45$ (1991)

17) N. Taniguchi, S. Seki, J. Fukai, and A. Kijima: Induction of two types of gynogenetic diploids by hydrostatic pressure shock and verification by genetic marker in ayu. Nippon Suisan Gakkaisht, 54, 1483-1491 (1988).

18) H. S. Han, N. Taniguchi, and A. Tsujimura: Production of clonal ayu by chromosome manipulation and confirmation by isozyme marker and tissue grafting. Nippon Suisan Gakkaishi, 57, 825-832 (1991)

19) N. Taniguchi, A. Kijima, J. Fukai, and Y. Inada: Conditions to induce triploid and gynogenetic diploid in ayu Plecoglossus altivelis. Nippon Suisan Gakkaishi, 52, 49-53 (1986).

20) E. M. Southern: Detection of specific sequences among DNA fragments separated by gel electrophoresis. $J_{+} \mathrm{Mol}$ Biol. 98, 503-517 (1975)

21) A. P. Feinberg and B. Vogelstein: A technique for radiolabelling DNA restriction endonuclease fragments to high specific activity. Anal. Biochem., 137, 266-267 (1984).

22) J. H. Wetton, R. E. Carter, D. T. Parkin, and D. Walters: Demographic study of a wild house sparrow population by DNA fingerprinting. Nature, 327, 147-149 (1987).

23) A. J. Jeffreys, V. Wilson, S. L. Thein, D. J. Weatherall, and B. A. J. Ponder: DNA 'fingerprints' and segregational analysis of multiple markers in human pedigrees. Amer. $J$. Human Ganet., 39, 11-24 (1986)

24) A. J. Jeffreys and D. B. Morton: DNA fingerprints of dogs and cats. Anim. Genet., 18, 1-15 (1987).

25) J. Hillel, Y. Plotzy, A. Haberfeld, U. Lavi, A. Cahaner, and A. J. Jeffreys: DNA fingerprints of poultry. Anim. Genet. 20, 145-155 (1989).

26) T. Burke and $M$. W. Bruford: DNA fingerprinting in birds Nature, 327, 149-152 (1987).

27) F. W. Allendorf and R. F. Leary: Heterozygosity in gynogenetic diploids and triploids estinated by genecentromere recombination rates. Aquaculture, 43, $413-420$ (1984),

28) N. Taniguchi, H. Hatanaka, and S. Seki: Genetic variation in quantitative characters of meotic- and mitotic-gynogenetic diploid ayu, Plecoglossus altivelis. Aquaculture, 85, 223-233 (1990). 